https://helda.helsinki.fi

\title{
Derivational networks in Finnish
}

\section{Pitkänen-Heikkilä, Kaarina}

De Gruyter Mouton

2020-06-08

Pitkänen-Heikkilä , K 2020 , Derivational networks in Finnish . in L Körtvélyessy , A

pÿBagasheva \& P ‘tekauer (eds), Derivational Networks Across Languages. Trends in Linguistics. Studies and Monographs [TiLSM], 340 , De Gruyter Mouton , Berlin ; Boston , pp. 373-384 . https://doi.org/10.1515/9783110686630-038

http://hdl.handle.net/10138/322059

https://doi.org/10.1515/9783110686630-038

cc_by_nc_nd

acceptedVersion

Downloaded from Helda, University of Helsinki institutional repository.

This is an electronic reprint of the original article.

This reprint may differ from the original in pagination and typographic detail.

Please cite the original version. 


\section{Derivational networks in Finnish \\ Kaarina Pitkänen-Heikkilä}

\section{General notes}

Derivation in Finnish is accomplished mainly through suffixation, and prefixation is not characteristic of Finnish word-formation. Finnish has systematically avoided verbal prefixes even though it has been influenced by many languages that have them. It does, however, have certain prefix-like particles that form compounds with verbs (Bikupska 2018: 15.) Nouns and adjectives in present-day Finnish, it will be noted, may have short compounding forms (often borrowed, e.g. anti-, eko-, etä- 'far') that could also be seen as prefixes (Tyysteri 2015: 125). Possible word-formation with prefixes is excluded from the Finnish data in this research. The only clear cases would be epätietoinen 'unaware' (negative epä- + tietoinen 'counscious, aware' < tietää 'know') and its further derivatives, which are considered compounds in Finnish and are therefore also excluded from this data.

Finnish has almost 200 derivational types - over 100 nominal and adjectival suffixes and about 50 verbal suffixes. Pitkänen-Heikkilä (2016) describes the most common of these in English. The Iso suomen kielioppi ('Comprehensive Finnish Grammar', 2004) introduces 48 types of noun derivatives, 27 types of verb derivatives, 7 types of adverb derivatives and 15 types of adjective derivatives, excluding participles, ordinal numbers and comparison forms (Hakulinen et al. 2004: 195-196, 297-298, 365). Lauri Hakulinen (1967) lists a total of 88 denominal nominal suffixes, 46 deverbal nominal suffixes, 31 deverbal verbal suffixes and 17 denominal verbal suffixes (L. Hakulinen 1967: 246). Many Finnish derivational types do not appear in this research because certain types can only be added to certain root types, and the chosen 30 base words do not include all of them.

It is worth pointing out that complete derivational maps are very difficult to produce in Finnish. Intuition does not necessarily yield all derivatives in productive use and many are typically excluded from Finnish dictionaries (e.g. Hakulinen et al. 2004: 186). Established derivatives that appear in dictionaries tend to have some lexical meaning. Researchers seeking information on the actual usage of intuition-based derivatives may, however, find it from corpora or the Internet, e.g. by using Google search.

It should also be taken into consideration that derivational series are not always clear in suffixal derivation (e.g. Räisänen 1978, Hakulinen et al. 2004: 182). It is possible to construe the verbal derivatives kaveta (PROCESS 'become narrower'), kaventaa (CAUSATIVE 
'make narrower') and kaventua (PROCESS 'become narrower') for the $1^{\text {st }}$ order of derivation from the adjective kapea 'narrow', for example, but the following derivational series is also feasible kapea > PROCESS kaveta > CAUSATIVE kaventaa > ANTICAUSATIVE kaventua, as shown in this study.

Derivation produces new words, whereas inflection does not. The distinctions between the two are not always clear, however. In particular, denominal verbs and deverbal nouns in Finnish include many borderline cases. Finnish words with the suffix -minen, for example, may be categorized as infinitive forms of verbs, or they may be totally excluded from nominal forms. Most commonly, however, they can be decoded as infinitives only with regard to some special syntactic tasks, otherwise as action name derivatives (Häkkinen 1990: 102).

Given the exclusion of participles in this study, certain common semantic categories show little or no attestation in this research. For example, UNDERGOER (agent participle, e.g. leikkaama 'to be cut by somebody') does not exist, ABILITY (e.g. active and passive participles leikkaava $a_{\mathrm{A}}$ 'cutting' and leikattava $a_{\mathrm{A}}$ 'cuttable', and further derivatives STATE leikkaavuus (piercingness', STATE leikattavuus $\mathrm{N}$ 'possibility to be cut') are rare, and QUALITY (e.g. participles leikattu 'operated on; cut; sterilized', leikannut $t_{\mathrm{A}}$ ) is even more rare. I have included only the $m A t O n$-suffix that produces PRIVATIVE (leikkaamaton ${ }_{\mathrm{A}}$ 'uncut') derivatives and is the negative equivalent of the agent participle.

It was challenging to find 30 real, underived words in Finnish for this data because many words that are perceived as simple words nowadays are historically derivatives. For example, ommella 'sew', is not an old underived simplex - the suffix -ele- is also transparent (ompele-). Because this project examines derivatives synchronically, I took in this word, too. As a consequence, however, the derivational map of this word does not allow for some typical first-order suffixes because the base word already has this iterative suffix. In addition, the adjectival base kapea 'narrow' is historically a derivative. The suffix $-e A$ is transparent, but the root and the meaning are not, and because of this $e A$-derivatives are often categorized as simplexes (e.g. Hakanen 1973). The oldest Finnish simplex roots have two syllables and end in $a$ or $\ddot{a}$. The sample of 30 words also includes different words (e.g. 'warm' lämmin: läm-pi$m \ddot{a}-)$, but from the point of view of modern Finnish they can be examined as simplex.

The equivalent of hold in Finnish is pitää, which is a highly polysemous word. In addition to meaning 'hold', it also means 'like', 'must' and 'keep'. The equivalent of burn is either palaa (intransitive) or polttaa (transitive). Palaa does not produce derivatives in most semantic categories, so the verb polttaa was selected. 
It is impossible to find all the actual derivatives without conducting more elaborate research. Derivatives of the $1^{\text {st }}$ order are often to be found in dictionaries (e.g. the frequently used Kielitoimiston sanakirja [The Dictionary of Standard Finnish]), whereas further orders should be searched for in Kielipankki (The Language Bank of Finland) corpora using Korp search, or via the internet using Google search. The verbal derivatives of the adjective paha 'bad' in the $1^{\text {st }}$ order of derivation, for instance, include PROCESS paheta 'get worse', CAUSATIVE pahoittaa 'make worse (somebody's mind)' and INCHOATIVE pahastua 'become offended', all of which appear in Kielitoimiston sanakirja. Korp search in Kielipankki yield further derivations in the ITERATIVE category, e.g. (pahastua $>$ ) pahastella in the $2^{\text {st }}$ order and (paheta $>$ pahentaa $>$ ) pahennella in the $3^{\text {rd }}$ order. Only one of these verbs, however, (pahoittaa 'make worse [somebody's feelings]') has a PRIVATIVE derivative (pahoittelematon in the $3^{\text {rd }}$ order) according to an internet search, although it is intuitionally clear that the two other iterative derivatives can also be combined with the privative suffix - $m A t O n$ (pahentelematon, pahastelematon).

Established, lexicalized derivatives are excluded from the data, which is why some common Finnish derivative types seem to be rare. Derivatives that occur as lexicalized forms may, at the same time, block their productive use as derivatives. Many Finnish two-syllable verb roots that end in $a$ or $\ddot{a}$ (e.g. vetää: vedä- 'pull', antaa: anna- 'give', kaivaa: kaiva'dig'), for example, produce resultative $O s$-derivatives (vedos, annos, kaivos). Many of these derivatives are lexicalized, however, and have special, established meanings (vedos 'proof', annos 'portion', kaivos 'mine'), and are excluded from this study. Even if they are structurally transparent, they are not necessarily easy to recognize as derivatives of those roots.

\section{Maximum derivational networks}

As Table 1 shows, the typical number of derivational orders in Finnish is 3 . The derivation of almost half (14) of the 30 words is in the $4^{\text {th }}$ order. There are rare cases of words with derivatives in the $5^{\text {th }}$ order.

\begin{tabular}{|l|l|l|l|l|l|l|}
\hline & $1^{\text {st }}$ order & $2^{\text {nd }}$ order & $3^{\text {rd }}$ order & $4^{\text {th }}$ order & $5^{\text {th }}$ order & $\Sigma$ \\
\hline Nouns & 33 & 34 & 21 & 7 & 2 & 97 \\
\hline Verbs & 34 & 37 & 19 & 9 & 1 & 100 \\
\hline Adjectives & 27 & 54 & 27 & 12 & 2 & 122 \\
\hline TOTAL & 94 & 125 & 67 & 28 & 5 & 319 \\
\hline
\end{tabular}

Table 1 Maximum derivational networks per order of derivation for all three word-classes 


\section{Saturation values}

As tables 2-4 show, the highest mean saturation values per word-class are $57 \%$ for verbs (leikata 'cut'), 52\% for adjectives (uusi 'new'), and 46\% for nouns (päivä 'day'). The lowest main values are $8 \%$ for nouns (täi 'louse'), 11\% for verbs (polttaa 'burn') and 13\% for adjectives (musta 'black').

\begin{tabular}{|l|l|l|l|l|l|l|l|}
\hline \multicolumn{2}{|l|}{ Nouns } & $\begin{array}{l}\text { Saturation } \\
\text { value }(\%)\end{array}$ & $\begin{array}{l}1^{\text {st }} \text { order } \\
(\%)\end{array}$ & $\begin{array}{l}2^{\text {nd }} \text { order } \\
(\%)\end{array}$ & $\begin{array}{l}3^{\text {rd }} \text { order } \\
(\%)\end{array}$ & $\begin{array}{l}4^{\text {th }} \text { order } \\
(\%)\end{array}$ & $\begin{array}{l}5^{\text {th }} \text { order } \\
(\%)\end{array}$ \\
\hline luu & 'bone' & 24.74 & 24.24 & 35.29 & 19.05 & 0 & 0 \\
\hline silmä & 'eye' & 35.05 & 42.42 & 41.18 & 28.57 & 0 & 0 \\
\hline hammas & 'tooth' & 29.9 & 42.42 & 32.35 & 19.05 & 0 & 0 \\
\hline päivä & 'day' & 46.39 & 30.3 & 44.12 & 52.38 & 100 & 100 \\
\hline koira & 'dog' & 15.46 & 30.3 & 14.71 & 0 & 0 & 0 \\
\hline täi & 'louse' & 8.25 & 18.18 & 5.88 & 0 & 0 & 0 \\
\hline tuli & 'fire' & 25.77 & 24.24 & 32.35 & 23.81 & 14.29 & 0 \\
\hline kivi & 'stone' & 42.27 & 27.27 & 58.82 & 52.38 & 14.29 & 0 \\
\hline vesi & 'water' & 29.9 & 36.36 & 32.35 & 28.57 & 0 & 0 \\
\hline nimi & 'name' & 40.21 & 36.36 & 58.82 & 33.33 & 0 & 0 \\
\hline
\end{tabular}

Table 2 Saturation values per order of derivation, nouns

Table 2 shows that the highest saturation value of nouns within the $1^{\text {st }}$ order is $42 \%$ (silmä 'eye' and hammas 'tooth'), in the $2^{\text {nd }}$ order 59\% (kivi 'stone' and nimi 'name') and in the $3^{\text {rd }}$ order 52\% (päivä 'day' and kivi 'stone'). The old Finnish noun täi 'louse' has the lowest saturation value in the $1^{\text {st }}, 2^{\text {nd }}$ and $3^{\text {rd }}$ orders of derivation. The nouns koira 'dog' and täi 'louse' do not have derivation in the $3^{\text {rd }}$ order, 3 nouns have derivations of the $4^{\text {th }}$ order and only one (päivä 'day') has a derivation of the $5^{\text {th }}$ order.

\begin{tabular}{|l|l|l|l|l|l|l|l|}
\hline \multicolumn{2}{|l|}{ Verbs } & $\begin{array}{l}\text { Saturation } \\
\text { value (\%) }\end{array}$ & $\begin{array}{l}1^{\text {st }} \text { order } \\
(\%)\end{array}$ & $\begin{array}{l}2^{\text {nd }} \text { order } \\
(\%)\end{array}$ & $\begin{array}{l}3^{\text {rd } \text { order }} \\
(\%)\end{array}$ & $\begin{array}{l}4^{\text {th }} \text { order } \\
(\%)\end{array}$ & $\begin{array}{l}5^{\text {th }} \text { order } \\
(\%)\end{array}$ \\
\hline leikata & 'cut' & 57 & 76.47 & 67.57 & 31.58 & 0 & 0 \\
\hline kaivaa & 'dig' & 29 & 41.18 & 29.73 & 21.05 & 0 & 0 \\
\hline vetä̈̈ & 'pull' & 24 & 38.24 & 29.73 & 0 & 0 & 0 \\
\hline heittää & 'throw' & 23 & 32.35 & 27.03 & 10.53 & 0 & 0 \\
\hline antaa & 'give' & 21 & 23.53 & 27.03 & 5.26 & 22.22 & 0 \\
\hline pitä̈̈ & 'hold' & 34 & 23.53 & 40.54 & 47.37 & 22.22 & 0 \\
\hline ommella & 'sew' & 19 & 23.53 & 16.22 & 21.05 & 11.11 & 0 \\
\hline polttaa & 'burn' & 11 & 20.59 & 10.81 & 0 & 0 & 0 \\
\hline juoda & 'drink' & 19 & 29.41 & 18.92 & 10.53 & 0 & 0 \\
\hline tietää & 'know' & 31 & 23.53 & 16.22 & 47.37 & 77.78 & 100 \\
\hline
\end{tabular}

Table 3 Saturation values per order of derivation, verbs

Table 3 shows that one verb has a $5^{\text {th }}$-order derivation (tietää ' $\left.k n o w '\right)$ and 4 have $4^{\text {th }}$-order derivations. The verb leikata 'cut' has the highest saturation values (76\% and $68 \%)$ in the $1^{\text {st }}$ 
and $2^{\text {nd }}$ orders, and in the $3^{\text {rd }}$ order the highest value is $47 \%$ for pitää 'hold' and tietää 'know', whereas that of the verb leikata is only $32 \%$.

\begin{tabular}{|l|l|l|l|l|l|l|l|}
\hline \multicolumn{2}{|l|}{ Adjectives } & $\begin{array}{l}\text { Saturation } \\
\text { value }(\%)\end{array}$ & $1^{\text {st }}$ order $(\%)$ & $\begin{array}{l}2^{\text {nd }} \text { order } \\
(\%)\end{array}$ & $\begin{array}{l}3^{\text {rd }} \\
(\%)\end{array}$ & $4^{\text {th }}$ order $(\%)$ & $\begin{array}{l}5^{\text {th }} \text { order } \\
(\%)\end{array}$ \\
\hline kapea & 'narrow' & 26.23 & 22.22 & 9.26 & 48.15 & 58.33 & 50 \\
\hline vanha & 'old' & 27.05 & 29.63 & 18.52 & 29.63 & 41.67 & 100 \\
\hline suora & 'straight' & 19.67 & 18.52 & 20.37 & 29.63 & 0 & 0 \\
\hline uusi & 'new' & 52.46 & 48.15 & 75.93 & 29.63 & 16.67 & 0 \\
\hline pitkä & 'long' & 38.52 & 40.74 & 20.37 & 70.37 & 50 & 0 \\
\hline lämmin & 'warm' & 27.87 & 33.33 & 31.48 & 29.63 & 0 & 0 \\
\hline paksu & 'thick' & 20.49 & 29.63 & 22.22 & 14.81 & 8.33 & 0 \\
\hline paha & 'bad' & 38.52 & 48.15 & 27.78 & 48.15 & 41.67 & 50 \\
\hline ohut & 'thin' & 25.41 & 22.22 & 7.41 & 40.74 & 75 & 50 \\
\hline musta & 'black' & 13.11 & 22.22 & 12.96 & 11.11 & 0 & 0 \\
\hline
\end{tabular}

Table 4 Saturation values per order of derivation, adjectives

As Table 4 shows, the adjectives with the highest saturation values $(48 \%)$ in the $1^{\text {st }}$ order are uusi 'new' and paha 'bad'; in the $2^{\text {nd }}$, the highest value is (76\%) attested for uusi, but in the $3^{\text {rd }}$ order it is $70 \%$ for pitkä 'long'. The words suora 'straight', lämmin 'warm' and musta 'black' have no $4^{\text {th }}$-order derivations, yet kapea 'narrow', vanha 'old', paha 'bad' and ohut 'thin' all attest $5^{\text {th }}$-order derivations.

\begin{tabular}{|l|l|l|l|l|l|}
\hline & $1^{\text {st }}$ order & $2^{\text {nd }}$ order & $3^{\text {rd }}$ order & $4^{\text {th }}$ order & $5^{\text {th }}$ order \\
\hline Nouns & 31.21 & 35.59 & 28.42 & 12.86 & 10 \\
\hline Verbs & 33.24 & 28.38 & 19.47 & 13.33 & 10 \\
\hline Adjectives & 31.48 & 24.63 & 35.19 & 30 & 25 \\
\hline
\end{tabular}

Table 5 Average saturation values per order of derivation for all three word-classes

As Table 5 shows, the average saturation values for all three word-classes do not differ critically in this data in the $1^{\text {st }}$ order of derivation: verbs have a slightly higher average value (33\%) than adjectives $(31 \%)$ and nouns $(31 \%)$. The average saturation value in the $2^{\text {nd }}$ order is $36 \%$ for nouns, $28 \%$ for verbs, and $25 \%$ for adjectives. The differences are clearer in the later orders of derivation: adjectives have higher saturation values (35\%) than nouns $(28 \%)$ and verbs $(19 \%)$ in the $3^{\text {rd }}$ order, and adjectives have clearly higher values than nouns and verbs in the $4^{\text {th }}$ and $5^{\text {th }}$ orders. The reason for the big differences in average values is the lack of $3^{\text {rd }}$ order derivation in some base words.

\section{Orders of derivation}

The maximum number of orders in the Finnish data is 5 for nouns, adjectives, and verbs. As Table 6 shows, the average number for nouns and verbs is 3.2, and 4.1 for adjectives. The low 
average for nouns and verbs reflects the fact that there are also two adjectives and two verbs that attest only 2 orders (koira 'dog', täi 'louse', vetää 'pull', polttaa 'burn').

\begin{tabular}{|l|l|l|}
\hline & Maximum & Average \\
\hline Nouns & 5 & 3.2 \\
\hline Verbs & 5 & 3.2 \\
\hline Adjectives & 5 & 4.1 \\
\hline
\end{tabular}

Table 6 Maximum and average numbers of orders of derivation for all three word-classes

\section{Derivational capacity}

The derivational capacity as shown in Table 7 covers only $1^{\text {st }}$-order derivatives. The average derivational capacity in the Finnish data is between 8.5 and 11.3 , even if the differences between the maximum capacities are bigger. The verb leikata 'cut' has the highest derivational capacity, with $261^{\text {st }}$-order derivatives. The maximum derivational capacity for nouns is 14, versus 13 for adjectives; they occur with the words silmä 'eye', hammas 'tooth' and uusi 'new'. Of the verbs, leikata has an exceptional capacity (26), and the others have only $7-141^{\text {st }}$-order derivatives.

\begin{tabular}{|l|l|l|}
\hline & Maximum & Average \\
\hline Nouns & 14 & 10.3 \\
\hline Verbs & 26 & 11.3 \\
\hline Adjectives & 13 & 8.5 \\
\hline
\end{tabular}

Table 7 Maximum and average derivational capacities for all three word-classes

There is no significant difference in average derivational capacity between nouns, verbs and adjectives. As illustrated in Table 8, however, adjectives have higher derivational capacity than nouns and verbs in the $2^{\text {nd }}-5^{\text {th }}$ orders. The differences are clearest in the $3^{\text {rd }}$ order of derivation: nouns and verbs have an average of 5.4 and 3.8 derivatives, respectively, whereas adjectives have 8.5 derivatives on average. The most prolific adjective in the $3^{\text {rd }}$ order is pitk $\ddot{a}$ 'long', with 19 derivatives. One verb (tietää 'know'), one noun (päivä 'day') and four adjectives (kapea 'narrow', vanha 'old', paha 'bad', ohut 'thin') have $5^{\text {th }}$-order derivation (e.g. paha 'bad' > CAUSATIVE pahoittaa $a_{\mathrm{V}}$ 'make worse (somebody's feelings)' > ITERATIVE pahoitella $_{\mathrm{V}}>$ PRIVATIVE pahoittelematon $_{\mathrm{A}}>$ STATIVE pahoittelemattomuus $_{\mathrm{N}}$ ).

\begin{tabular}{|l|l|l|l|l|l|}
\hline & $1^{\text {st }}$ order & $2^{\text {nd }}$ order & $3^{\text {rd }}$ order & $4^{\text {th }}$ order & $5^{\text {th }}$ order \\
\hline Nouns & 10.3 & 12.1 & 5.4 & 0.9 & 0.2 \\
\hline Verbs & 11.3 & 10.1 & 3.8 & 1.2 & 0.1 \\
\hline Adjectives & 8.5 & 13.3 & 8.5 & 3.2 & 0.5 \\
\hline
\end{tabular}




\section{Correlation between semantic categories and orders of derivation}

All the nouns in the $1^{\text {st }}$ order produce derivatives within the semantic categories SIMILATIVE and PRIVATIVE (e.g. kivi > kivimäinen 'stonelike' and kivetön 'without stone'), and 9 produce derivatives within the POSSESSIVE category (e.g. kivi > kivellinen 'with stone', gap for päivä 'day' that has a possessive suffix -llinen in its lexicalized use päivällinen 'dinner': I have categorized the productive use of this suffix as QUALITY: päivällinen 'of the day'). The category QUALITY has 8 nouns that produce adjectives mainly with the suffix -inen (e.g. kivinen 'stony'). In the $2^{\text {nd }}$ order, the semantic category STATIVE has 1-5 derivatives in each of the 10 noun bases, as all SIMILATIVE, PRIVATIVE and QUALITY adjectives can be derived with the suffix -UUs (e.g. kivimäisyys 'stonelikeness', kivettömyys 'lacking stones', kivisyys 'stoniness'). ACTION is also quite a common category in the $2^{\text {nd }}$ order of derivation, 8 nouns being represented under this label even with 4 different derivatives (e.g. kivi 'sten' > kivittää 'to stone' > kivitys 'stoning'; gaps for koira 'dog' and täi 'louse' that have no verb derivations in the $1^{\text {st }}$ order).

All the verbs in the $1^{\text {st }}$ order produce derivatives within the semantic categories ACTION, AGENT and PRIVATIVE (e.g. leikkaus 'cutting, surgical operation'; leikkaaja 'cutter'; leikkaamaton 'uncut'). In the $2^{\text {nd }}$ order, the semantic category STATIVE has 10 verbs that produce property names (e.g. leikkaamattomuus 'having not been cut' [lit. 'uncutness']), ACTION and AGENT have 8 verbs that produce action and agent names (e.g. leikkely 'cutting, dissecting', leikkauttaja 'one who has something cut'; gaps for ommella 'sew' and tietää 'know').

There is a strong correlation in Finnish adjectives between the $1^{\text {st }}$ order of derivation and the semantic categories STATE, PROCESS, ATTENUATIVE and MANNER. All these categories have 1-3 derivatives in any of the 10 adjectival bases of the sample (e.g. paha 'bad' > STATE pahuus 'badness'; PROCESS paheta 'get worse', ATTENUATIVE pahahko 'fairly bad' and MANNER pahasti 'badly'). An equally strong correlation is also present in the $2^{\text {nd }}$ order of derivation and the semantic categories PRIVATIVE and ACTION, as well as between the $3^{\text {rd }}$ order of derivation and the semantic category ACTION. These categories in the $2^{\text {nd }}$ order have 1-12 derivatives (e.g. pahuudeton $_{\mathrm{A}}$ 'without badness', paheksunta $_{\mathrm{N}}$ 'thinking ill of somebody, disapproval'), and ACTION in the $3^{\text {rd }}$ order has $1-4$ derivatives (e.g. pahastuttamine $n_{\mathrm{N}}$ 
'offending, displeasing', pahoittel $u_{\mathrm{N}}$ 'expression of regret') in each of the 10 adjectival bases of the sample.

\section{Semantic categories with blocking effects}

Blocking effects in Finnish are typically morphological, and hence are also extensive, i.e. - UUs that produces property names and -sti that produces adverbs block further derivation in this data. Thus, the semantic categories STATIVE (10 nouns in the $2^{\text {nd }}$ order, e.g. päivittäisyys $s_{\mathrm{N}}$ 'dailiness', koiramaisuus $_{\mathrm{N}}$ 'dog likeness') and MANNER (6 nouns in the $2^{\text {nd }}$ order, e.g. hampaattomasti $i_{\mathrm{ADV}}$ 'without teeth, toothlessly', kivisesti $i_{\mathrm{ADV}}$ 'stonily') block further derivation. With verbs, too, the semantic category STATIVE (10 verbs in the $2^{\text {nd }}$ order and 7 verbs in the $3^{\text {rd }}$ order, e.g. leikkaamattomuus $\mathrm{N}_{\mathrm{N}}$ 'having not cut; having not been cut') blocks further derivation. In addition, further derivation of adjectives is not possible in the categories STATIVE (e.g. 10 adjectives in the $1^{\text {st }}$ order such as vanhuus $s_{\mathrm{N}}$ 'old age', and 9 in the $3^{\text {rd }}$ order such as uudistamattomuus $\mathrm{N}_{\mathrm{N}}$ 'being unreconstructed') and MANNER (10 adjectives in the $1^{\text {st }}$ order such as pahasti $i_{\mathrm{ADV}}$ 'badly' and 5 in the $2^{\text {nd }}$ order such as lämpimähkösti $i_{\mathrm{ADV}}$ 'rather warmly').

Although adverbs ending -sti can usually be formed from adjectives, on the semantic level not all adjectives are suitable for expressing manner or quantity. Examples of these include adjectives that express color, age, shape or size and indicate a permanent and inherent property (e.g. ?sinisesti 'blue-ly', ?vanhasti 'old-ly', *kolmivuotiaasti 'three-year-old-ly') (Hakulinen et al. 2004: 367-368). However, some of such derivatives are recorded in metaphorical use in this data: mustasti 'black-ly', paksusti 'thick-ly', vanhasti 'old-ly, oldish'.

\section{Typical combinations of semantic categories}

Koivisto (2013) introduced Finnish derivation series using examples in which as many as 5 suffixes are attested, which according to Koivisto is the maximum number of consecutive suffixes in a root. Such complex derivatives are often difficult to understand, however, and are used rarely (Koivisto 2013: 180, 186).

Every verb derivative can be further derived with the suffix -mAtOn, which produces privative adjectives, and further with the suffix $-U U s$, which produces property names (e.g.

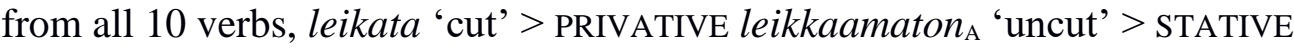
leikkaamattomuиs N $_{\mathrm{N}}$ having not cut; having not been cut'). All 10 adjectives and 8 nouns 
(blocks with täi 'louse' and koira 'dog') in the sample of Finnish data have verb derivatives of the $1^{\text {st }}$ order of derivation (semantic categories CAUSATIVE and/or PROCESS). Thus, typical combinations are CAUSATIVE-PRIVATIVE-STATIVE (e.g. päivä 'day' > CAUSATIVE päivätä 'date' > PRIVATIVE päiväämätöon $n_{\mathrm{A}}$ 'undated' > STATIVE päiväämättömyys N $_{\mathrm{N}}$ 'undatedness') and PROCESS-PRIVATIVE-STATIVE (e.g. musta 'black' > PROCESS mustua $a_{\mathrm{V}}$ 'become black' >

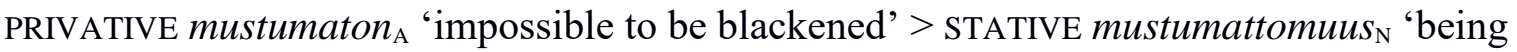
impossible to be blackened'). In addition, a typical combination for adjective bases is the verbal series PROCESS-CAUSATIVE-ANTICAUSATIVE (10 PROCESS in the $1^{\text {st }}$ order, a further 9 CAUSATIVE in the $2^{\text {nd }}$ order, and 5 ANTICAUSATIVE in the $3^{\text {rd }}$ order of derivation, e.g. paha 'bad' > PROCESS paheta v $_{\mathrm{V}}$ 'get worse' > CAUSATIVE pahentaa $_{\mathrm{V}}$ 'make worse' > ANTICAUSATIVE pahentua $_{\mathrm{V}}$ 'get worse').

In addition, it is possible to derive action and agent names from all verbs. Typical combinations are CAUSATIVE-ACTION and CAUSATIVE-AGENT, as well as PROCESS-ACTION and PROCESS-PATIENT. For example, 8 nouns, 10 adjectives and 8 verbs have action names in the

$2^{\text {nd }}$ step, whereas 6 nouns, 7 adjectives and 8 verbs have agent names in the $2^{\text {nd }}$ step as they have verbal derivatives in the $1^{\text {st }}$ step (e.g. nimi 'name' > CAUSATIVE nimittä̈̈̈ 'nominate' > ACTION nimity $_{\mathrm{N}}$ 'nomination'; nimi 'name' > CAUSATIVE nimet $\ddot{a}_{\mathrm{V}}$ 'to name' > AGENT nimeäj $\ddot{\mathrm{N}}_{\mathrm{N}}$ 'who gives the name'; leikata 'cut' > CAUSATIVE leikkauttaa $a_{\mathrm{V}}$ 'to have something cut by somebody' > ACTION leikkauttaminen ${ }_{\mathrm{N}}$ 'having something cut by somebody'; tuli 'fire' $>$ CAUSATIVE tulittaa $_{\mathrm{V}}$ 'to fire, shoot' > AGENT tulittaja $a_{\mathrm{N}}$ 'who fires').

\section{Multiple occurrences of semantic categories}

Causative verbs are productive in Finnish, and many can be derived further for the meaning of commission: such derivatives can be called curatives. For example, all the 10 adjectives in the sample have causative verbs in the $1^{\text {st }}$ or $2^{\text {nd }}$ order of derivation, and they all have new causative (curative) verbs in the $2^{\text {nd }}$ or $3^{\text {rd }}$ order. It is a typical Finnish CAUSATIVE-CAUSATIVE combination, for example, lämmin 'warm' > lämmittää ${ }_{\mathrm{V}}$ 'to warm, heat' > lämmityttää 'to have something (e.g. house) heated', pitkä 'long' > pitkittä̈̈ 'prolong, lengthen' > pitkityttä̈̈̈ 'to have something (e.g. time) lengthened', ohut 'thin'>ohentaa $a_{\mathrm{v}}$ 'to thin, dilute' $>$ ohennuttaa $_{\mathrm{V}}$ 'to have something (e.g. hair) thinned'.

\section{The reversibility of semantic categories}


Certain semantic categories may occur multiple times in series of derivations in which consecutive adjective and adverb suffixes are possible, and also in the opposite order. For example, MANNER-QUALITY and QUALITY-MANNER are possible even in the same series, e.g.

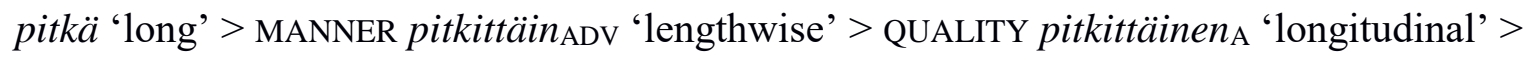
MANNER pitkittäisest $i_{\mathrm{ADV}}$ 'longitudinally'. The adverbs pitkittäin and pitkittäisesti are almost synonymous, however. This is, however, a unique case. There is also a noun that attests to the

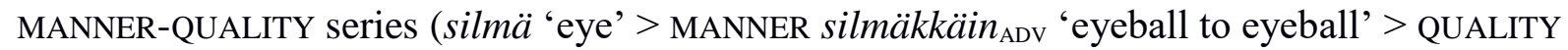
silmäkkäinen $_{\mathrm{A}}$ ), but it cannot be derived further to MANNER (silmäkkäisesti $i_{\mathrm{ADV}}$ is a potential and possible Finnish word, but I did not find any occurrences of it).

\section{Conclusions}

The average number of derivational orders ranges between 3.2 to 4.1 in the Finnish data. As Koivisto (2013: 186) claims, it also is possible to form longer combinations with suffixes, but very long formations may well be difficult to use and understand. There are 3 nouns, 4 verbs and 7 adjectives that have $4^{\text {th }}$-order derivations, and 1 noun, 1 verb and 4 adjectives that have $5^{\text {th }}$-order derivations. Adjectives yield the richest derivational maps, 10 base words producing 354 derivatives: the most productive base is uusi 'new' with 64 derivatives. The count of derivatives among the 10 nouns is 288 , the most productive being päivä 'day' with 44 . With regard to verbs the derivational map produces 268 derivatives, and leikata 'cut' is the most productive with 57.

In sum, the derivatives of 30 Finnish base words are assigned to 31 different semantic categories based on the data used for this study. The most frequent categories are ACTION, AGENT, PATIENT, QUALITY, POSSESSIVE, SIMILATIVE, ATTENUATIVE, DURATIVE, PRIVATIVE, PROCESS, CAUSATIVE, ITERATIVE, STATE and MANNER. Some categories are used rather seldom: these include ENTITY, DEMINUTIVE, REFLEXIVE, SUBITIVE, INSTRUMENTATIVE, ANTICAUSATIVE, EXPERIENCER, LOCATION, AUGMENTATIVE, RESULTATIVE and COLLECTIVE. Derivatives in the ABILITY, INCHOATIVE, OCCUPATION, FEMININE, RELATIONAL and TEMPORAL categories are the rarest in this data. In some cases the reason for the low frequency (ABILITY, INCHOATIVE, RESULTATIVE) or total absence (UNDERGOER) is that the chosen base words do not represent all possible semantic and morphological types, and because of the exclusion of participles. Although the abundance of deverbal verbal suffixes (e.g. categories DURATIVE, ITERATIVE, REFLEXIVE, SUBITIVE) are considered one of the distinguishing features of Finnish compared to Indo-European languages (e.g. Karlsson 2015: 278), they are not strongly 
emphasized in this data. Possibly this is, however, reflected in Table 5, which shows the highest saturation for verbs in the $1^{\text {st }}$ order of derivation, for nouns in the $2^{\text {nd }}$ order and for adjectives in the $3^{\text {rd }}$ order.

\section{References}

Bikupska, Anna-Maija 2018 Verbi verbistä: Puolan ja suomen johdetun verbileksikon merkitysrakenteen vertailua. [A verb for a verb: A comparative study of the semantic structure of derived verb lexicon in Polish and Finnish University of Helsinki.] http://hdl.handle.net/10138/232239

Hakanen, Aimo 1973 Adjektiivien vastakohtasuhteet suomen kielessä. [Opposite relations of adjectives in Finnish.] SKST 311. Helsinki: SKS.

Hakulinen, Auli, Maria Vilkuna, Riitta Korhonen, Vesa Koivisto, Tarja Riitta Heinonen, Irja Alho 2004 Iso suomen kielioppi. [The Comprehensive Finnish Grammar.] SKST 950. Helsinki: SKS.

Hakulinen, Lauri [1941, 1946] 1979 Suomen kielen rakenne ja kehitys. [The structure and development of the Finnish language.] Fourth, revised edition. Helsinki: Otava.

Häkkinen, Kaisa 1990 Mistä sanat tulevat? Suomalaista etymologiaa. [Where words come from? Finnish etymology.] Tietolipas 117. Helsinki: SKS.

Karlsson, Fred 2015 Finnish. An Essential Grammar. $3^{\text {rd }}$ edition. Routledge Essential Grammars. London \& New York.

Koivisto, Vesa 2013 Suomen sanojen rakenne. [Structure of Finnish words.] Helsinki: SKS

Pitkänen-Heikkilä, Kaarina 2016 176. Finnish. - Peter O. Müller, Ingeborg Ohnheiser, Susan Olsen, Franz Rainer (eds.), Word-Formation. An International Handbook of the Languages of Europe. Vol 5. Handbooks of Linguistics and Communication Sciences. 32093228. Mouton de Gruyter. 
Räisänen, Alpo 1978 Kantasanan ja johdoksen suhteesta. [From the relationship between base and derivative.] - Virittäjä 100: 321-344.

Tyysteri, Laura 2015 Aamiaiskahvilasta ötökkätarjontaan. Suomen kirjoitetun yleiskielen morfosyntaktisten yhdyssanarakenteiden produktiivisuus. [Productivity of morphosyntactic compound structures in written Finnish standard language.] Annalis Universitatis Turkuensis C: 408. Scripta Lingua Fennica Edita. Turku.

\section{Sources}

Internet (Google searching https://www.google.com/)

Kielipankki. The Language Bank of Finland. https://www.kielipankki.fi/language-bank/ Kielitoimiston sanakirja. [Dictionary of standard Finnish.]

https://www.kielitoimistonsanakirja.fi/

Korp - the corpus infrastructure of Språkbanken. Lars Borin, Markus Forsberg and Johan Roxendal. 2012. https://korp.csc.fi/ 